\title{
A Study on the Failure of Steel Chains in Rotary Cement Kilns
}

\author{
M. A. M. Al-Moussawi ${ }^{1,2}$
}

Received: 25 August 2017 / Revised: 22 December 2017 / Accepted: 15 January 2018 / Published online: 30 January 2018

(c) The Author(s) 2018. This article is an open access publication

\begin{abstract}
The failure of steel chains which are used in rotary cement kilns costs cement companies a significant price. This study investigated the causes of chains failure at the Kufa cement plant and proposes new materials that can serve for a prolonged period of time. Two grades of steel chains were investigated including DIN 1.4742 (AISI 10F) and St37. Ten samples of chains from different locations from the kiln flame have been taken after 30 days and after 180 days of continuous work inside the rotary cement kiln. To study the effect of the distance from the kiln flame on the DIN 1.4742 (AISI 10F), another two samples have been replaced the St37 grade at a distance of $28.2 \mathrm{~m}$. Chemical analysis for each sample under study has been carried out in order to highlight the differences between the used chain and the original chain in terms of alloying elements weight. An optical images of the unused and used chains of DIN 1.4742 (AISI 10F) steel grade have been taken to understand that the change occurs in the grain size. SEM-EDS technique was also applied to understand the possible segregation of elements. The results showed that the decrease of alloying elements pct, especially $\mathrm{Cr}$, in the microstructure was the main reason of chain failure by corrosion/erosion mechanism. Preventing $\mathrm{Cr}$ from segregation can prolong the life of kiln chains during service. The study suggests new steel grades to replace DIN 1.4742 (AISI 10F) and St37 steel grades.
\end{abstract}

Keywords Steel chains $\cdot$ Cement kilns $\cdot$ Cr segregation

\section{Introduction}

Chains in wet and long-dry rotary cement kilns usually work as a removal of the moisture from the raw cement materials (mud), and it is also cleaning the kiln shell by transporting materials, crushing the mud rings, reducing the dust amount, and reducing the kiln exit gas temperature. Figure 1 shows a sketch to the rotary cement kiln including the chain locations (called also curtains) and the process of cement manufacturing [1]. The raw material enters the rotary cement (wet feed) with a temperature of $40^{\circ} \mathrm{C}$, while it discharges from the kiln with a temperature of $200{ }^{\circ} \mathrm{C}$. The gas enters the kiln with a temperature usually ranged from 700 to $760{ }^{\circ} \mathrm{C}$ and exits with a temperature of $180{ }^{\circ} \mathrm{C}$. These ranges of temperatures input and exit are controlled by the chains; any issues in the chains including failure due to breakage during the kiln operation can affect the product (clinker) quality and may result in air pollution. Figure 2 is a real

\section{A. M. Al-Moussawi}

inj.mun@atu.edu.iq; acesma4@exchange.shu.ac.uk

Al-Furat Al-Awsat Technical University, Kufa, Iraq

2 Sheffield Hallam University, Sheffield, UK image of chains curtain inside rotary cement kiln at "Kufa cement plant" which is under concern in this study, while Fig. 3 shows the relationship between energy consumption with and without using chain curtains [2]. The use of chains which made of carbon steel has caused in reduction in energy consumption from 1870 to $1730 \mathrm{kcal} / \mathrm{kg}$, while using heat resistance chains cased in energy consumption of $1500 \mathrm{kcal} / \mathrm{kg}$. Chains usually experience complicated thermo-chemical-mechanical conditions during cement kiln operation. Gas temperatures can reach to $800{ }^{\circ} \mathrm{C}$ in the first row of chains, while the temperature of raw material in contact with the chains is about $200{ }^{\circ} \mathrm{C}$ as shown in Fig. 4 [2]. Materials selection of chains usually depends on the location and the type of fuel used in cement kiln, high resistance steel grades are preferable in the first rows of chain curtains, while cheaper steel grades can be used in a distance far away from the flame to reduce the cost. Steel grades include carbon steel (AISI C1020, C1022, C1035), alloy steel (SAE 4140 and 8620), stainless ferritic steel (AISI 8F, 9F, and 10F), stainless austenitic steel (AISI 304, 329, 309, 310, and 321), and the very high resistance steel grades which have been developed by adding Mn element to increase the protection of $\mathrm{Ni}$ and $\mathrm{Cr}$ alloying elements. Figure 5 shows the ideal 


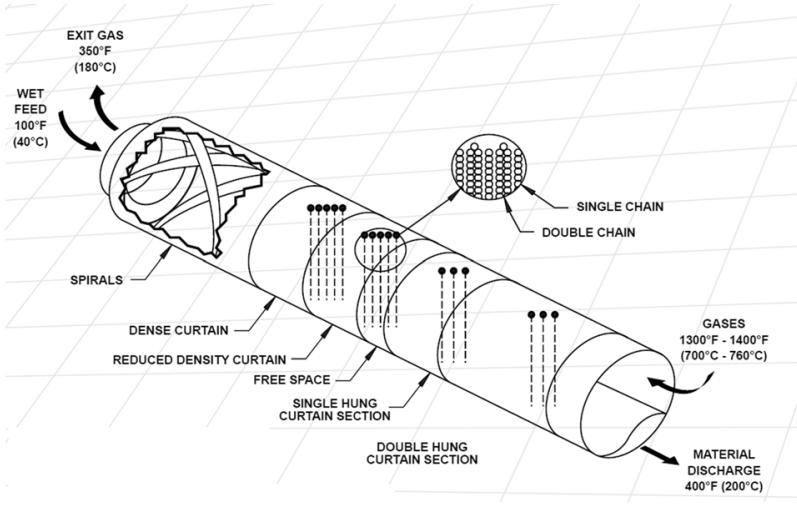

Fig. 1 A sketch to the rotary cement kiln including the chain locations (curtains) and the process of cement manufacturing [1]

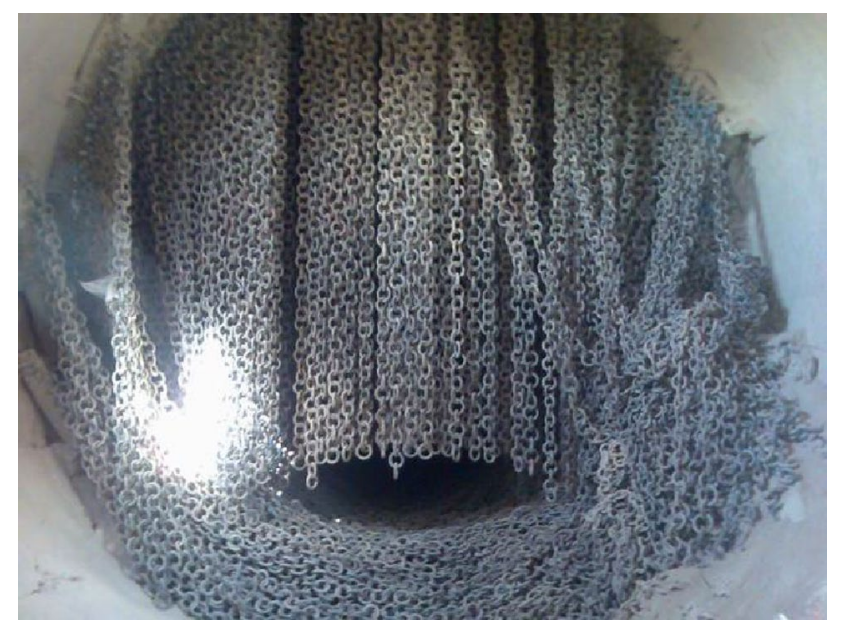

Fig. 2 A real image of chains curtain inside rotary cement kiln at Kufa cement plant. Courtesy of Kufa cement plant (image no. CK-005)

suggested layout of chains designed by Heko Ketten company, Germany, which depends on the fuel type [2]. Kiln chains usually last for maximum of 10-12 months depending on the operation conditions and the type of steel grades [Kufa cement plant records]. Issues of corrosion, deformation, and brittleness especially in the top ring of the chain are the most causes of the chains failure. Figure 6a-e shows different types of chains failure after serving for different period of time ranging from 6 to 8 months [Kufa cement plant]. The failures include (a) reduction in thickness and deformation, (b) oval deformation in the top ring, (c) reduction in thickness, oval and twisting deformation in the top ring, and (d) brittle cracking.

Previous work on cement kiln chains is limited for industrial companies which produce these products such as Heko Ketten, Germany, and AMH, Canada. Corrosion and chromium segregation represent the most issues that can lead to kiln chains failure. Stavrev and Dikova [3] investigated the structural changes of cement kiln chains grade DIN 1.4892 105MA Ni, Cr, Mn steel. They found that a reduction of $30 \%$ of chains thickness has occurred after 120 days of continuous service as a result of the corrosion and the mechanical effect of the mud. The microstructure of the chains which exposed to a temperature fluctuation above $700{ }^{\circ} \mathrm{C}$ was found to experience recrystallization. This in turn has resulted in a pit character and corrosion-fatigue cracks under the cyclic mechanical load. This crack was then propagated toward the depth of the chain and caused the final failure by breakage. Park et al. 2013 [4] applied immersing of weathering steels in $16.9 \mathrm{vol} . \% \mathrm{H} 2 \mathrm{SO} 4+0.35 \mathrm{vol} . \% \mathrm{HCl}$ at $60{ }^{\circ} \mathrm{C}$ in order to investigate the effect of $\mathrm{Cr}$ on corrosion resistance. $\mathrm{Cr}$ segregation at grain boundaries was found to increase when $\mathrm{Cu}$ elements exist in steel. They found that microgalvanic corrosion was the mechanism of Cr segregation as the grain acts as anode, whereas the grain boundary acts as cathode. The localized segregation of $\mathrm{Cr}$ has been found to cause in pitting corrosion which in turn caused in a reduction in the steel thickness. Saraf et al. [5] found that $\mathrm{Cr}$ diffusion in $\mathrm{Ni} / \mathrm{Cr}$ steels is the main issue that can reduce the corrosion resistance in steel. The $\mathrm{Cr}$ was found to segregate at the high-angle grain boundaries, and the angular misorientation between two grains is the driver of $\mathrm{Cr}$ segregation. Laws and Goodhew [6] investigated the relationship between Cr segregation and grain boundary structure of AISI 316 stainless steel using analytical electron microscopy technique (AEM). They found that the summation of boundaries which is equal to 9 was resulted in more $\mathrm{Cr}$ concentration rather than other grain boundaries. Defilippi and Chao [7] found that a band-like segregation pattern of chromium and molybdenum occurs in 434 stainless steel when hot rolling carried out in the temperature range of austenite and ferrite phase diagram. This type of segregation has classified as detrimental because it has led to ridging recrystallization.

The current work aims to understand the causes of kiln chains failure of Kufa cement plant by taking many samples of chains from different locations starting from the first row until $28.2 \mathrm{~m}$. Two time periods of continuous operation have been chosen ( 30 and 180 days) in order to understand the progress of failure with time. Chemical analysis, optical microscopy, and SEM-EDS techniques have been employed to investigate the possible phase change, grain growth, and elemental segregation.

\section{Materials and Methods}

Kufa cement plant depends on a wet process production with 4881 chains inside the rotary cement kiln, and each chain includes 45 rings. Heavy oil has been used as a fuel during 
Fig. 3 The relationship between energy consumption with and without using chain curtains [2]
Fig. 4 The typical distribution of temperature of gas and material along the kiln length [2]

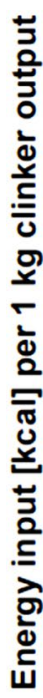

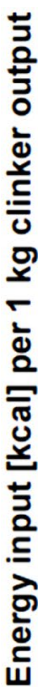

Increase of clinker output

Energy consuption

$\mathrm{Kcal} / \mathrm{kg}$

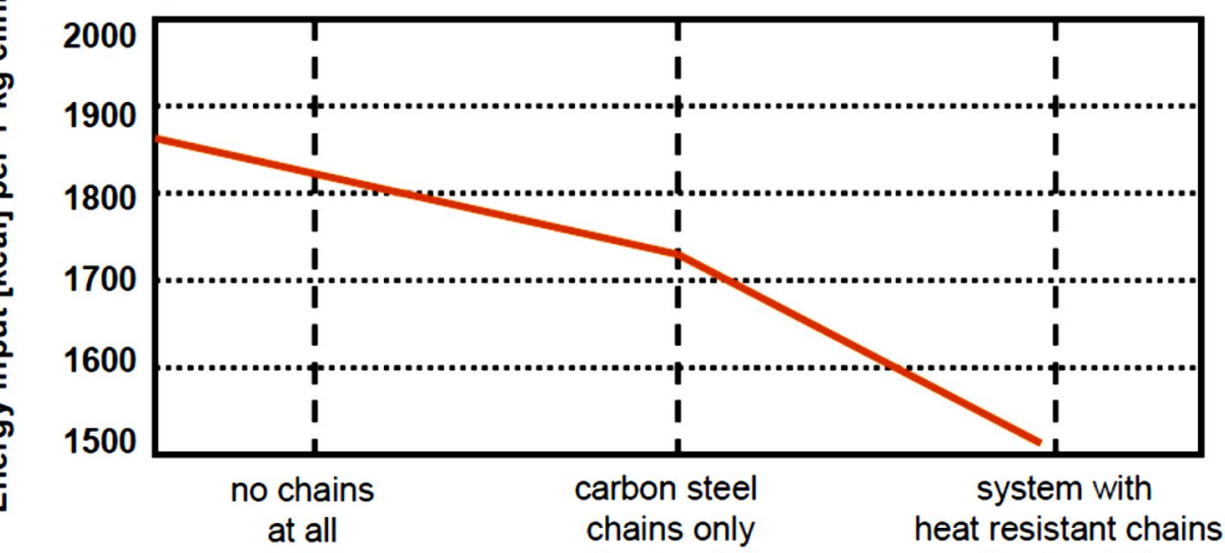

(System 'A')

(System 'C')

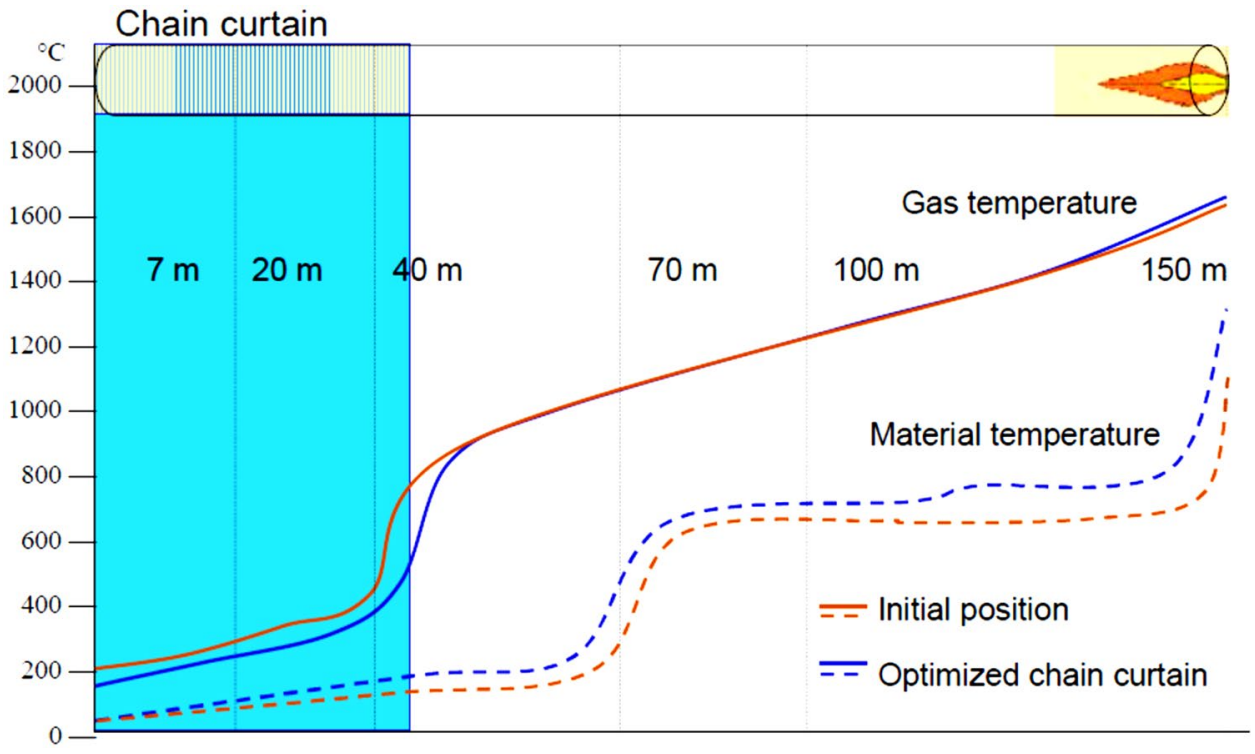

cement kiln continuous operation. Two types of steel grades are in service, DIN 1.4742 grade with ring dimension of (80 $\phi \times 20$ thick) usually located at the first four meters of the kiln chains curtain. The other cheaper steel grade is St37 with ring dimensions of $(81 \phi \times 25$ thick and $65 \phi \times 20$ thick) depending on the location from the kiln flame. The chemical composition of the material under study is shown in Table 1 which includes 1.4742 (AISI F10) and St37 steel grades.

\section{Chains Collection and Preparation}

Ten rings have been collected from different locations starting from the first raw until $28.2 \mathrm{~m}$ from the curtain, and these rings have been experienced maximum operational temperature of $800{ }^{\circ} \mathrm{C}$ at the first raw for 30 days of continuous working. Two rings were taken from each location including the top and bottom ring in order to compare the chemical analysis and the change in dimensions. The same mentioned method of samples collection has been carried out after 180 days of continuous work inside the rotary cement kiln. In total, 11 rings were collected 


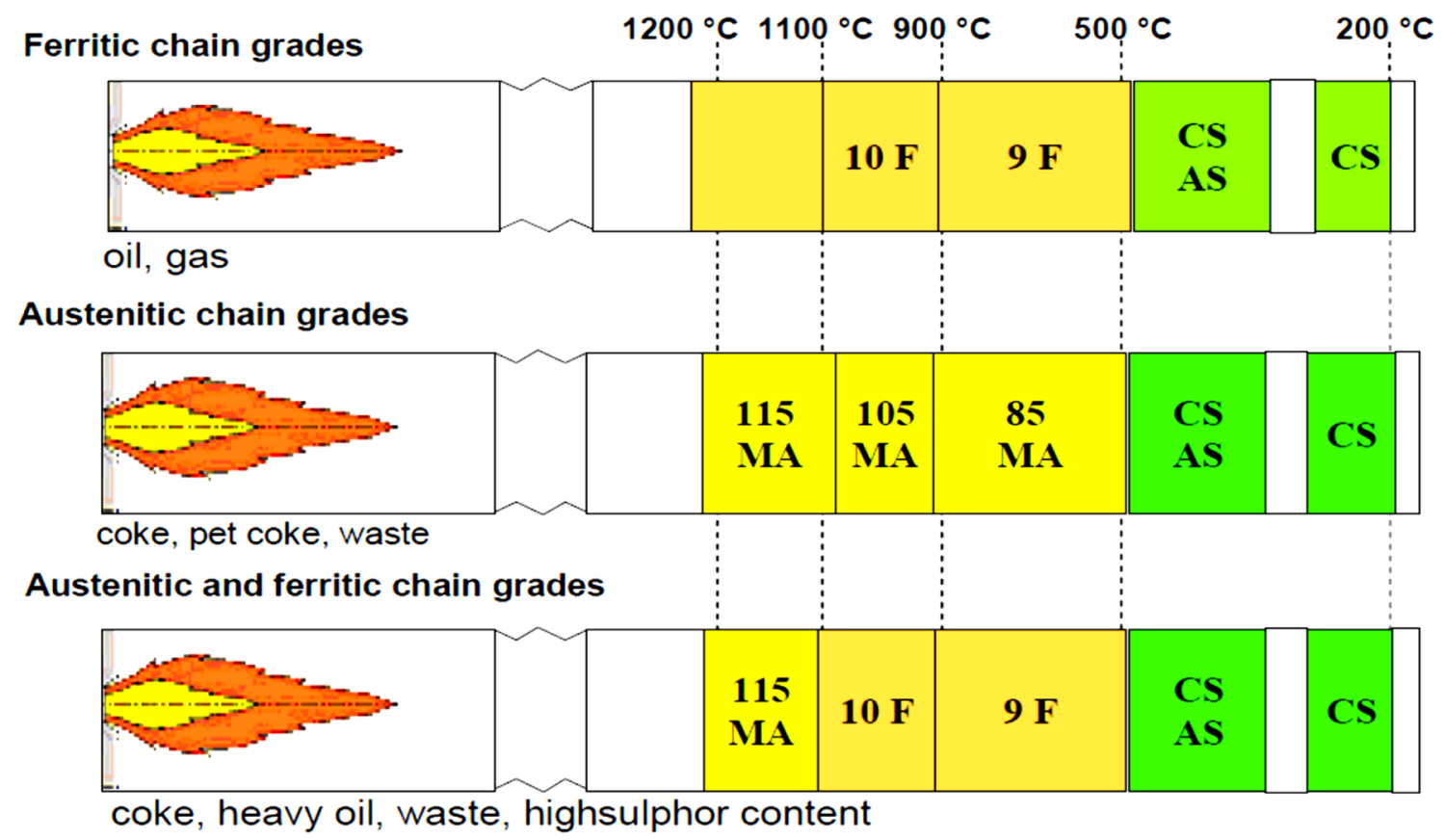

Fig. 5 The ideal suggested layout of chains designed by Heko Ketten company, Germany, which depends on the fuel type [2]. CS—carbo steel, AS-austenitic steel, 9F and 10F-ferritic steels, 115MA, 105MA, and 85MA—new developed austenitic manganese steels

including top and bottom rings, and the last ring at $28.2 \mathrm{~m}$ made of 1.4742 (AISI F10) steel grade has been replaced St 37 grade on the purpose to study the effect of the distance from fire on the change of chain chemical composition and dimensions. The reductions in chain thickness and diameter have been measured accurately using digital vernier calliper. Each ring has been cut into two halves using electric saw in order to take a cross-sectional specimen ( $2 \mathrm{~mm}$ thick) for chemical analysis. (Specimens can be taken from any position on the chain as the whole chain was experienced a uniform thermo-chemical-mechanical effect.) For optical microscopy and SEM-EDS tests, crosssectional specimens of $10 \mathrm{~mm}$ thick were taken from each steel ring. Grinding, polishing, and etching by $2 \%$ nital have been applied for microscopy purpose.

\section{Chemical Analysis}

Chemical analysis using inductively coupled plasma (ICP) has been carried out on each ring specimen in order to calculate the chemical weight (wt.\%) for elements starting from $\mathrm{C}$ to Fe. Model JY48P ICP atomic emission spectrometer was used. Twenty-two elements of 1.4742 (AISI F10) steel grade and twenty-six elements for $\mathrm{St} 37$ steel grade have been analyzed. Specimens were acidified with $1 \%$ ultrapure hydrochloric acid and nitric acid in order to dissolve the metal. The salts have been dissolved with hydrochloric acid (7-8 N) and extracted three times with methyl isobutyl ketone (MIBK). More details about the ICP technique can be found in Yoshihide and Noritaka [8].

\section{Optical Microscopy}

Optical images of 1.4742 (AISI F10) including unused, used for 30 days and used for 180 days have been produced to highlight the possible change in the microstructure grain sizes. Images were obtained using (Lyceum microscope).

\section{SEM Images and SEM-EDS Analysis}

Energy-dispersive x-ray spectroscopy EDS-SEM was carried out on the polished and etched (2\% nital) samples using FEI Nova Nano SEM in order to analyze the possible segregation of elements. The SEM produced high-quality and high-resolution images of microconstituents by employing secondary electron (SE) imaging mode with accelerated voltage $20 \mathrm{kV}$ which gives high penetration. The working distance (WD) used was $5 \mathrm{~mm}$ but in some cases altered (decreased or increased) to enhance the contrast at high magnification. The main aim for this microstructural assessment is to generate important information regarding the elements segregation in steel. 


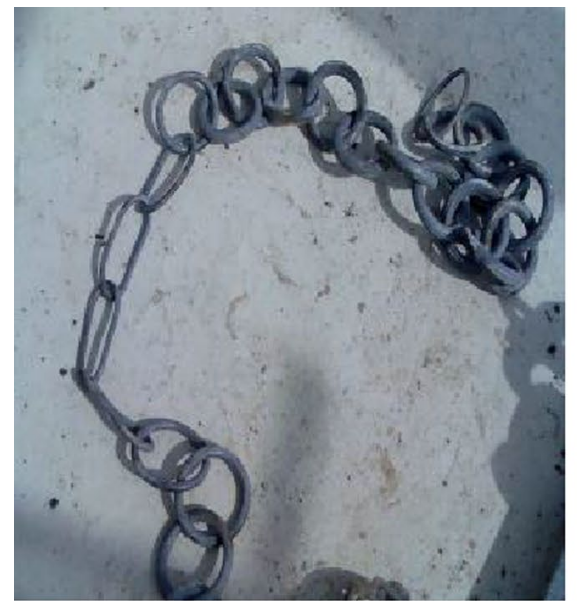

a

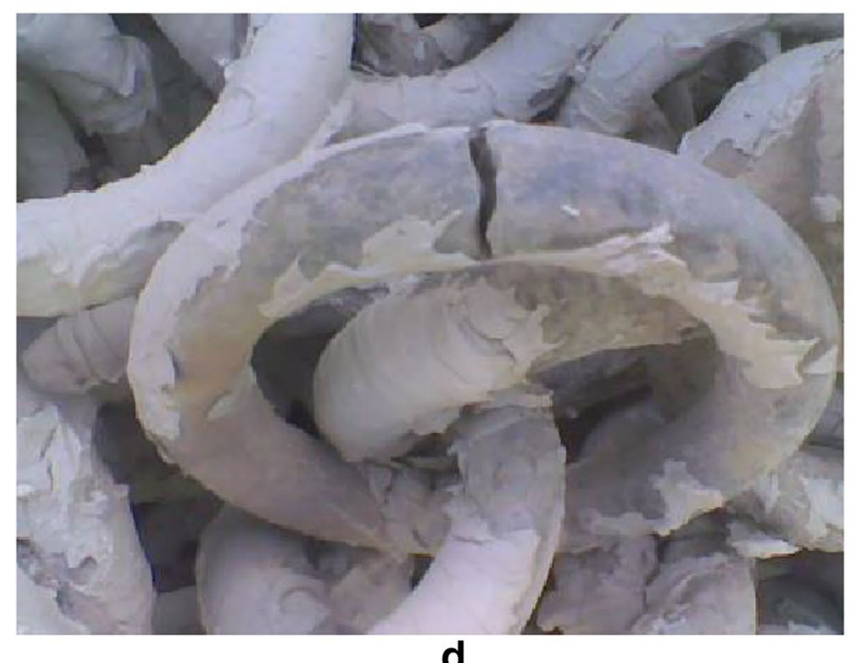

d

Fig. 6 Different types of chains failure, (a) reduction in thickness and deformation (St37 grade), (b) oval deformation in the first ring, 1.4742 (AISI F10). (c) Reduction in thickness, oval, and twisting deformation in the first ring 1.4742 (AISI F10). (d) Brittle cracking

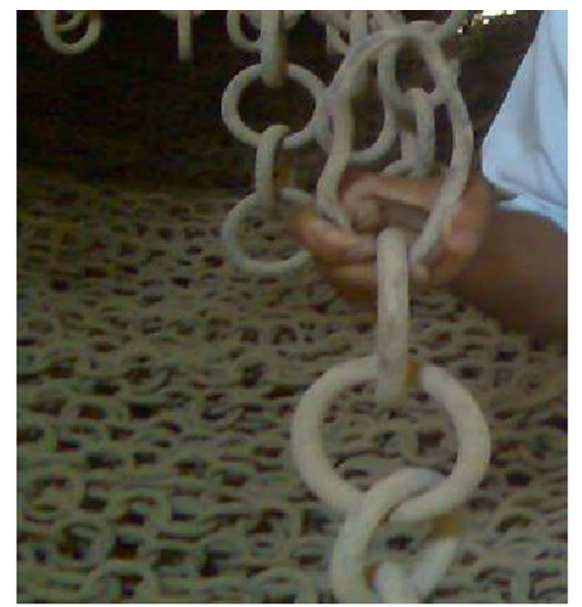

C

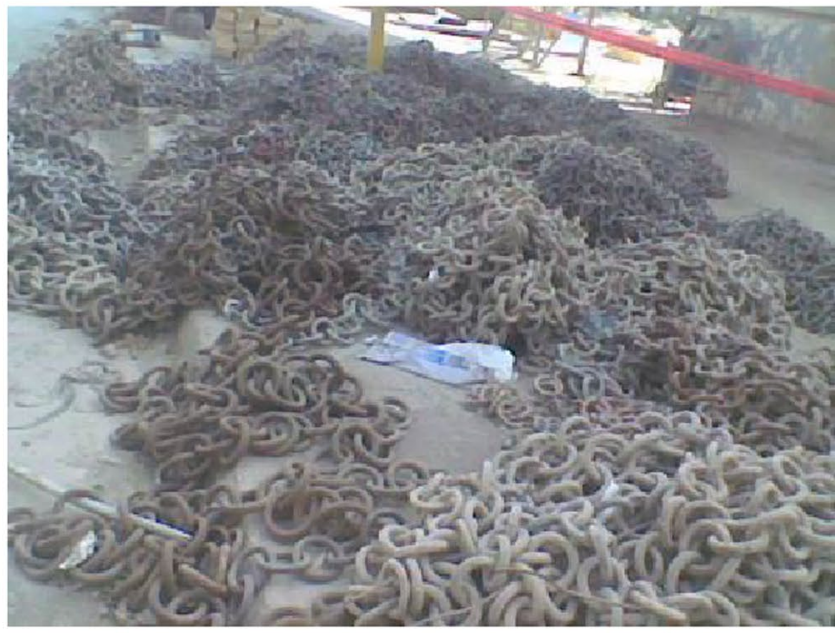

e

(DIN 1.4892 105MA) and (e) different types of failed chains dropped outside the cement kiln. Courtesy of Kufa cement plant (image no. CK-007-CK011)

Table 1 Chemical Composition of DIN 1.4742 (AISI F10) and St37 Steel Grades (wt.\%)

\begin{tabular}{llllllllllll}
\hline & $\mathrm{C} \%$ & $\mathrm{Si} \%$ & $\mathrm{Mn} \%$ & $\mathrm{P} \%$ & $\mathrm{~S} \%$ & $\mathrm{Cr} \%$ & $\mathrm{Ni} \%$ & $\mathrm{Mo} \%$ & $\mathrm{Al} \%$ & $\mathrm{Cu} \%$ & $\mathrm{Co} \%$ \\
\hline 1.4742 & 0.12 & 1.2 & 1 & 0.04 & 0.015 & 19 & 0.6 & 0.12 & 1.2 & 0.2 & 0.018 \\
$\mathrm{St37}$ & 0.17 & 0.3 & 1.4 & 0.05 & 0.05 & 0.3 & 0.3 & 0.05 & 0.05 & 0.4 & 0.1 \\
\hline & $\mathrm{Ti} \%$ & $\mathrm{Nb} \%$ & $\mathrm{~V} \%$ & $\mathrm{~W} \%$ & $\mathrm{~Pb} \%$ & $\mathrm{~B} \%$ & $\mathrm{Sn} \%$ & $\mathrm{As} \%$ & $\mathrm{Bi} \%$ & $\mathrm{Ca} \%$ & $\mathrm{Fe} \%$ \\
\hline 1.4742 & 0.01 & 0.01 & 0.048 & 0.01 & 0.003 & 0.001 & 0.011 & 0.0057 & 0.0015 & 0.0005 & $\mathrm{Balance}$ \\
$\mathrm{St37}$ & 0.03 & 0.03 & 0.03 & 0.1 & 0.05 & 0.0005 & 0.024 & 0.014 & 0.002 & 0.0003 & Balance \\
\hline
\end{tabular}

\section{Microhardness Measurement}

Measuring the hardness can give a good estimation for the microstructure without examining the morphology. Hardness was measured using Vickers microhardness device (HV) by applying 300-gf load with a diamond indenter. The measurement was taken along the horizontal and vertical surfaces of the samples under study in order to increase the accuracy. 


\section{Results}

\section{Samples Collection and Preparation}

Figures 7 and 8 show the collected samples after continuous work inside the rotary cement kiln for 30 and 180 days, respectively. The samples arranged according to the distance and deformation, and each sample has been cut into two halves in order to take a specimen for chemical analysis, optical, and SEM-EDS tests. The details of samples location, materials type, actual dimensions, and the original dimensions are listed in Tables 2 and 3 for 30 and 180 days of continuous work, respectively.

\section{Optical and SEM-EDS of Unused 1.4742 Chain}

Figure 9 is an optical image that shows the microstructure of unused 1.4742 chains, and the SEM-EDS of the elemental precipitates is shown in Figs. 10 and 11.
Optical, SEM-EDS, and Chemical Analysis of the Used Chains

Figure 12a and $\mathrm{b}$ shows optical and SEM images of 1.4742 steel (top ring) chain after using for 30 days inside the rotary cement kiln. Figures 13, 14, 15, and 16 show optical, SEMEDS, and SEM images, respectively, of 1.4742 steel (top ring) chain after using for 180 days inside the rotary cement kiln. Figure 17 is an SEM-EDS mapping for the segregated elements. Table 4 shows the results of ICP chemical analysis of ring 1 to ring 21 . Table 5 summarizes the loss of chromium and carbon due to segregation for all the samples under study, while Table 6 suggests alternative steel grades that may hold for longer time inside the rotary cement kiln.

\section{Discussion}

\section{Chains Deformation and the Reduction in Thickness}

Table 2 shows the change in ring dimensions after 30 days of serving inside Kufa rotary cement kiln. The top ring of 1.4742 grade at the first row (sample 1) has shown the maximum reduction in thickness $(2 \mathrm{~mm})$, while the bottom
Fig. 7 Samples of chains taken from different distances from the fire of cement kiln after 30 days of continuous work, each sample has been cut into two halves, and cross-sectional specimens were taken from each half for chemical analysis and imaging test. The location of the samples has been assigned to the left of the image, whereas the steel grade was assigned to the right of the image

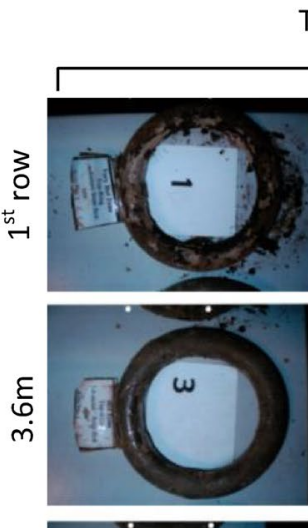

Top
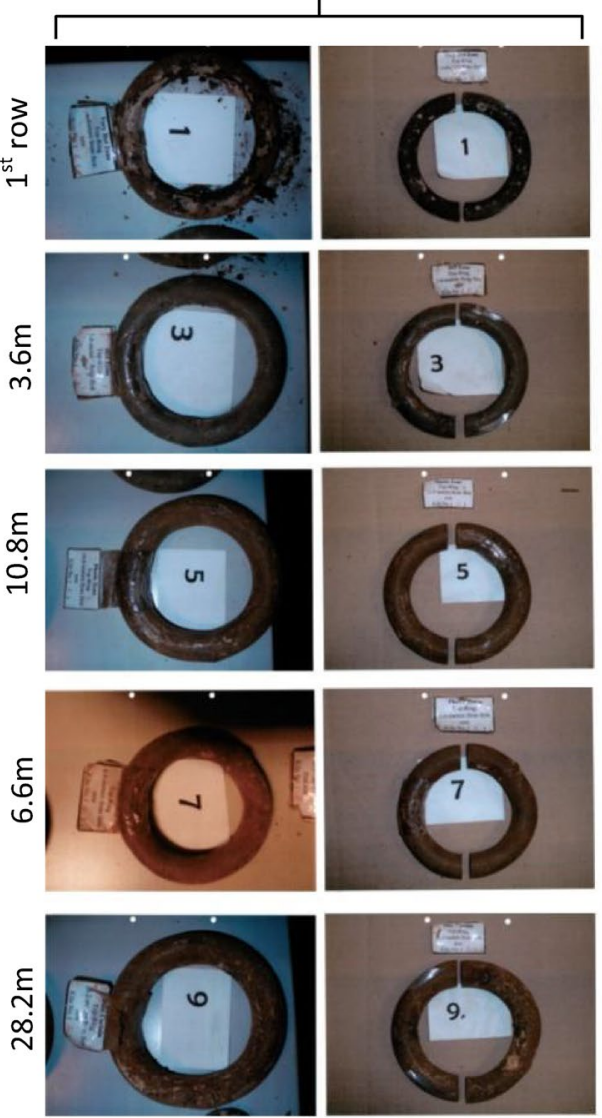
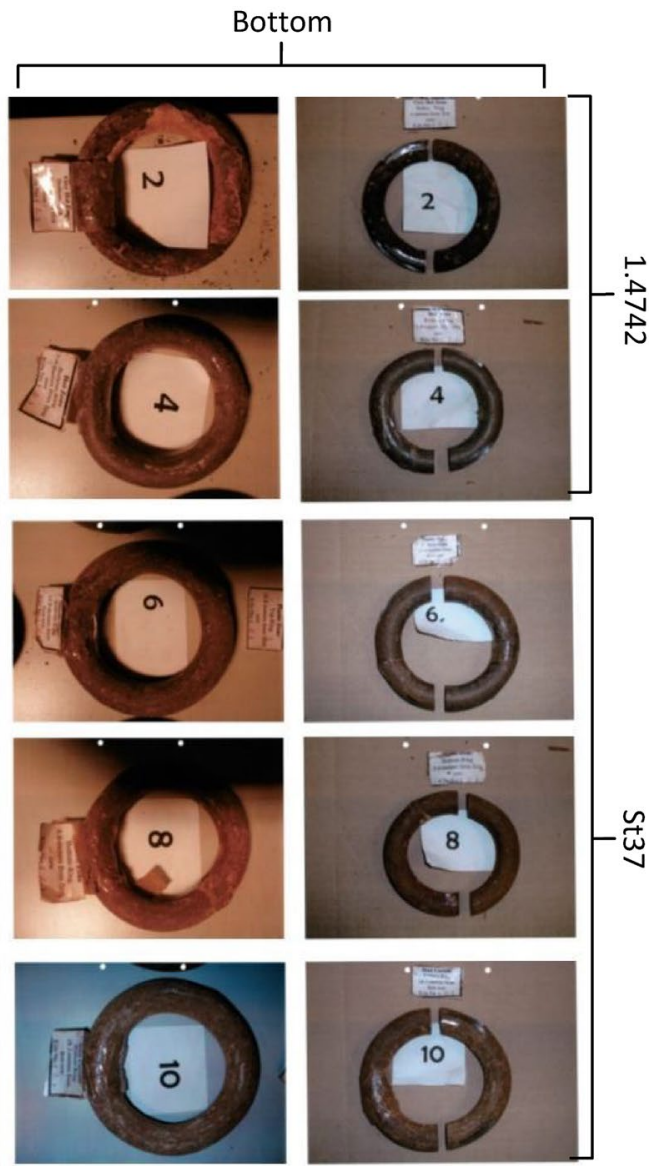
Fig. 8 Samples of chains taken from different distances from the fire of cement kiln after 180 days of continuous work, each sample has been cut into two halves, and cross-sectional specimens were taken from each half for chemical analysis and imaging test. The location of the samples has been assigned to the left of the image, whereas the steel grade was assigned to the right of the image



Top
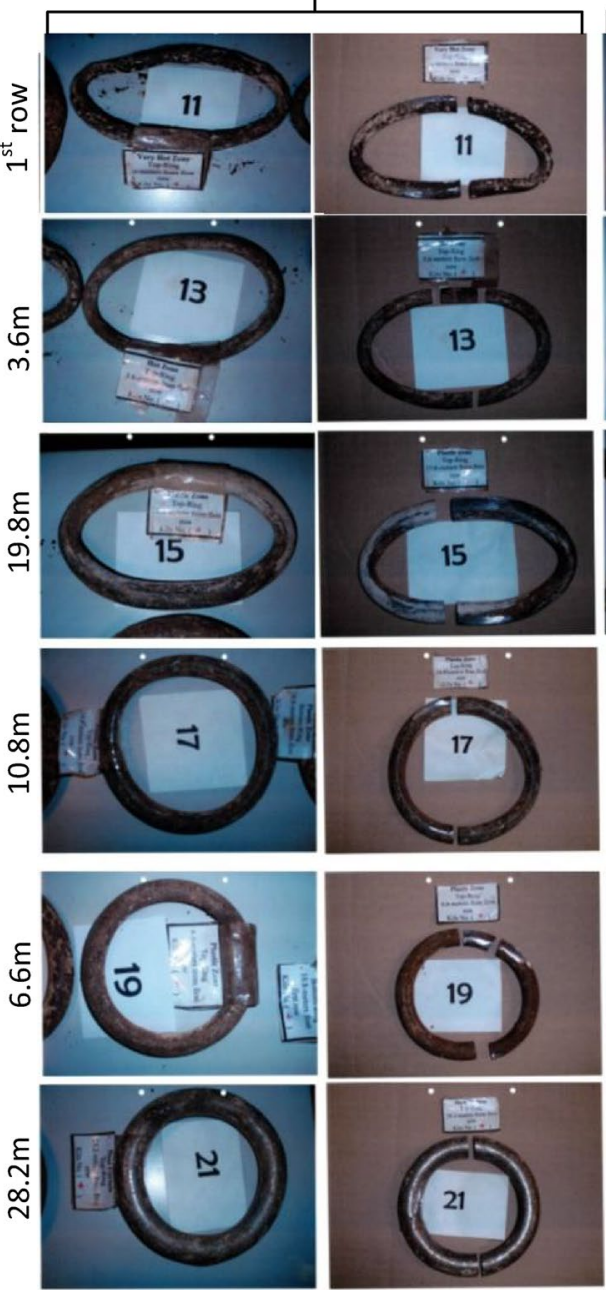

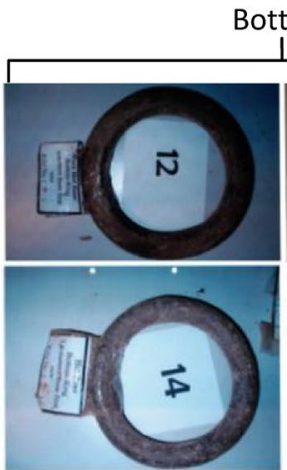

Bottom
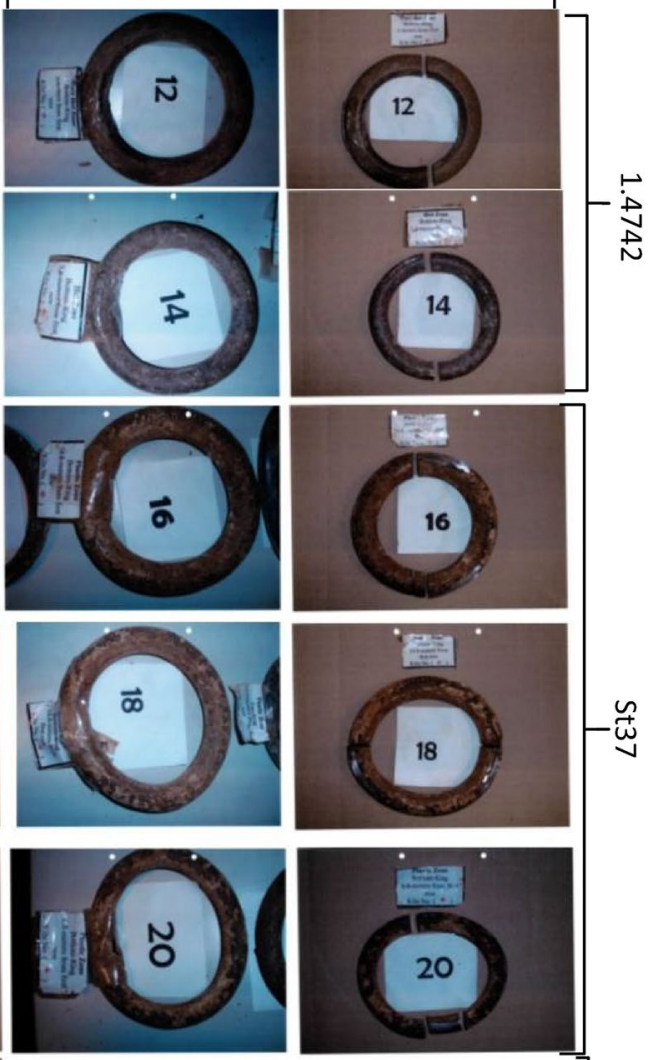

$\stackrel{\vec{D}}{N}$

Table 2 The details of the deformation and the distance from the kiln flame for the top and bottom chains ( 30 days of continuous using)

\begin{tabular}{|c|c|c|c|c|c|c|c|c|}
\hline \multirow[t]{2}{*}{ Sample no. } & \multirow{2}{*}{$\begin{array}{l}\text { Distance from } \\
\text { the fire, } m\end{array}$} & \multirow[t]{2}{*}{ Top/bottom } & \multicolumn{2}{|c|}{ Actual dimensions mm } & \multicolumn{2}{|c|}{ Original dimensions $\mathrm{mm}$} & \multirow{2}{*}{$\begin{array}{l}\text { Reduction in } \\
\text { thickness, mm }\end{array}$} & \multirow[t]{2}{*}{ Actual material } \\
\hline & & & Thickness & Diameter & Thickness & Diameter & & \\
\hline 1 & 1st raw & Top & 18 & 80 & 20 & 80 & 2 & 14.742 \\
\hline 2 & 1st raw & Bottom & 20 & 80 & 20 & 80 & 0 & 14.742 \\
\hline 3 & $3.6 \mathrm{~m}$ & Top & 20 & 80 & 20 & 80 & 0 & 14.742 \\
\hline 4 & $3.6 \mathrm{~m}$ & Bottom & 20 & 65 & 20 & 65 & 0 & 14.742 \\
\hline 7 & $6.6 \mathrm{~m}$ & Top & $14-19$ & 65 & 20 & 65 & $6-1$ & St 37 \\
\hline 8 & $6.6 \mathrm{~m}$ & Bottom & 19 & 65 & 20 & 65 & 1 & St 37 \\
\hline 5 & $10.8 \mathrm{~m}$ & Top & 24 & 80 & 25 & 81 & 1 & St 37 \\
\hline 6 & $10.8 \mathrm{~m}$ & Bottom & 25 & 80 & 25 & 81 & 0 & St 37 \\
\hline 9 & $28.2 \mathrm{~m}$ & Top & 24 & 80 & 25 & 81 & 1 & St 37 \\
\hline 10 & $28.2 \mathrm{~m}$ & Bottom & 25 & 80 & 25 & 81 & 0 & St 37 \\
\hline
\end{tabular}

ring was not affected. The reduction in thickness of the top ring can be related to corrosion abrasion of the ring surface which resulted from the thermo-chemical-mechanical effects. The top ring carries all other 44 rings which weigh together $35.2 \mathrm{~kg}$, add to that the effect of drag forces when the chains are in contact with the mud during kiln rotation. The abrasion between the surfaces of the top ring and the second ring in a corrosive environment during 
Table 3 The details of the deformation and the distance from the kiln flame for the top and bottom chains (180 days of continuous using)

\begin{tabular}{|c|c|c|c|c|c|c|c|c|}
\hline \multirow[t]{2}{*}{ Sample no. } & \multirow{2}{*}{$\begin{array}{l}\text { Distance from } \\
\text { the fire, } m\end{array}$} & \multirow[t]{2}{*}{ Top/bottom } & \multicolumn{2}{|c|}{ Actual dimensions mm } & \multicolumn{2}{|c|}{ Original dimensions $\mathrm{mm}$} & \multirow{2}{*}{$\begin{array}{l}\text { Reduction in } \\
\text { thickness, mm }\end{array}$} & \multirow[t]{2}{*}{ Actual material } \\
\hline & & & Thickness & Diameter & Thickness & Diameter & & \\
\hline 11 & 1st raw & Top & 13 & $50-120$ & 20 & 80 & 7 & 1.4742 \\
\hline 12 & 1st raw & Bottom & 19 & 80 & 20 & 80 & 1 & 1.4742 \\
\hline 13 & $3.6 \mathrm{~m}$ & Top & 11 & $62-111$ & 20 & 80 & 9 & 1.4742 \\
\hline 14 & $3.6 \mathrm{~m}$ & Bottom & 14 & 70 & 20 & 65 & 6 & 1.4742 \\
\hline 19 & $6.6 \mathrm{~m}$ & Top & 13 & $66-77$ & 20 & 65 & 7 & St 37 \\
\hline 20 & $6.6 \mathrm{~m}$ & Bottom & 13 & 74 & 20 & 65 & 7 & St 37 \\
\hline 17 & $10.8 \mathrm{~m}$ & Top & 15 & 92 & 25 & 81 & 10 & St 37 \\
\hline 18 & $10.8 \mathrm{~m}$ & Bottom & 19 & $80-90$ & 25 & 81 & 6 & St 37 \\
\hline 15 & $19.8 \mathrm{~m}$ & Top & 16 & $58-121$ & 25 & 81 & 9 & St 37 \\
\hline 16 & $19.8 \mathrm{~m}$ & Bottom & 21 & 81 & 25 & 81 & 4 & St 37 \\
\hline 21 & $28.2 \mathrm{~m}$ & Top & 18 & 77 & 25 & 81 & 7 & 1.4742 \\
\hline
\end{tabular}

Fig. 9 Optical microscopy image of DIN 1.4742 (AISI F10), average grain size is $10 \mu \mathrm{m}$. The black spot is the second-phase precipitates including $\mathrm{AlN}$ and $\mathrm{Cr}$

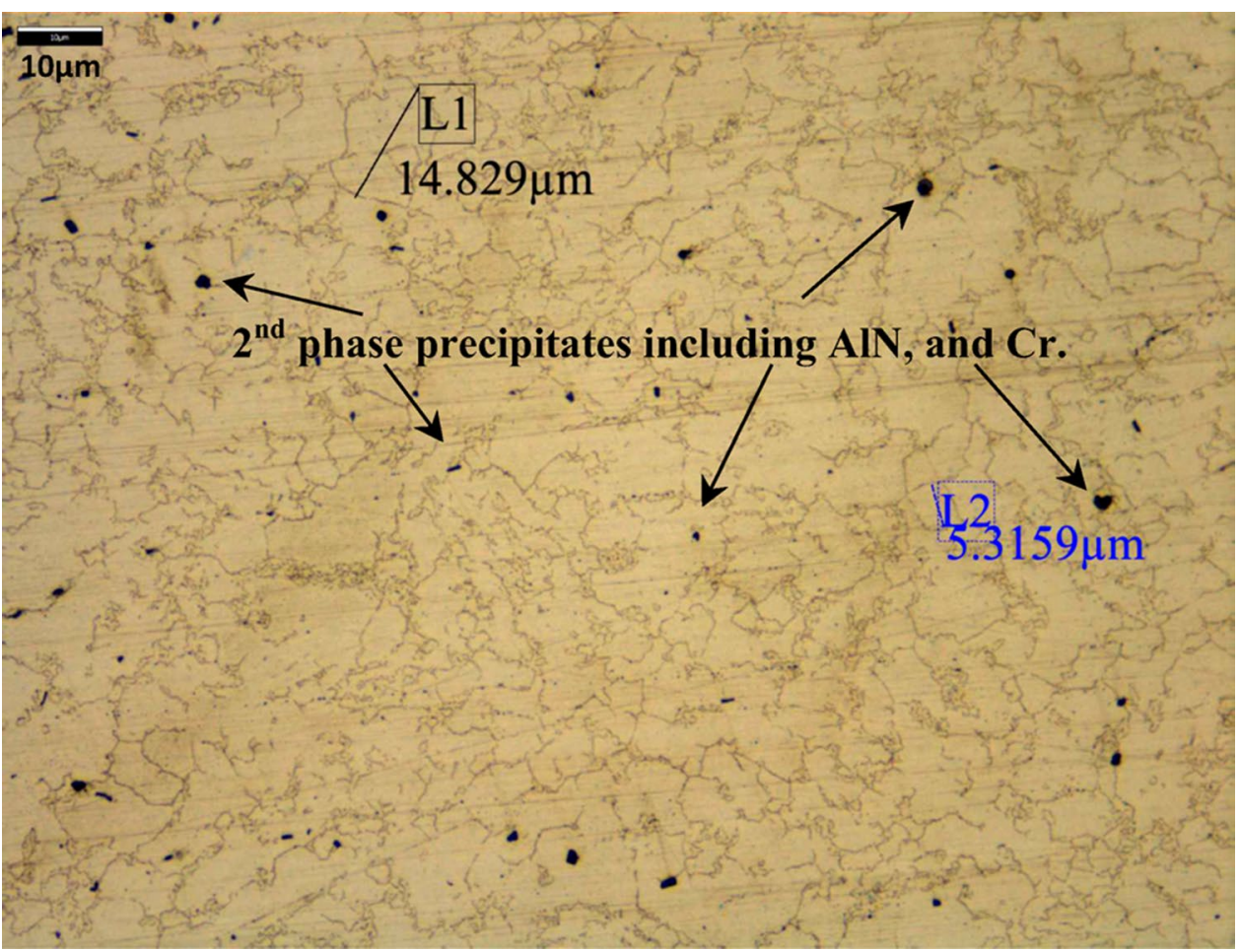

the kiln rotation can be the main reason of top ring thickness reduction. This was also clear in the top ring of $\mathrm{St} 37$ steel grade (sample 7) where the ring lost 1-6 mm from its original thickness. Top rings of sample 5 and sample 9 have experienced a reduction in thickness of $1 \mathrm{~mm}$ for the same mentioned thermo-chemical-mechanical effects. It is worth to highlight that rings with a distance closer to kiln fire (sample 1 and sample 7) have experienced more reduction in thickness compared to other rings. The original diameter of 1.4742 grade samples does not affect by creep after serving for 30 days as this grade includes high percentage of $\mathrm{Cr}, \mathrm{Ni}$, and other elements (see Table 1) which enabled the microstructure to resist the creep phenomenon. The differs in atoms size of the alloying elements exist in steel alloy can interrupts the arrangement order of the iron atoms in the lattice space and thus the creep by sliding mechanism will be difficult to occur [9]. Rings of St37 grade including samples 5, 6, 9, and 10 have shown a 


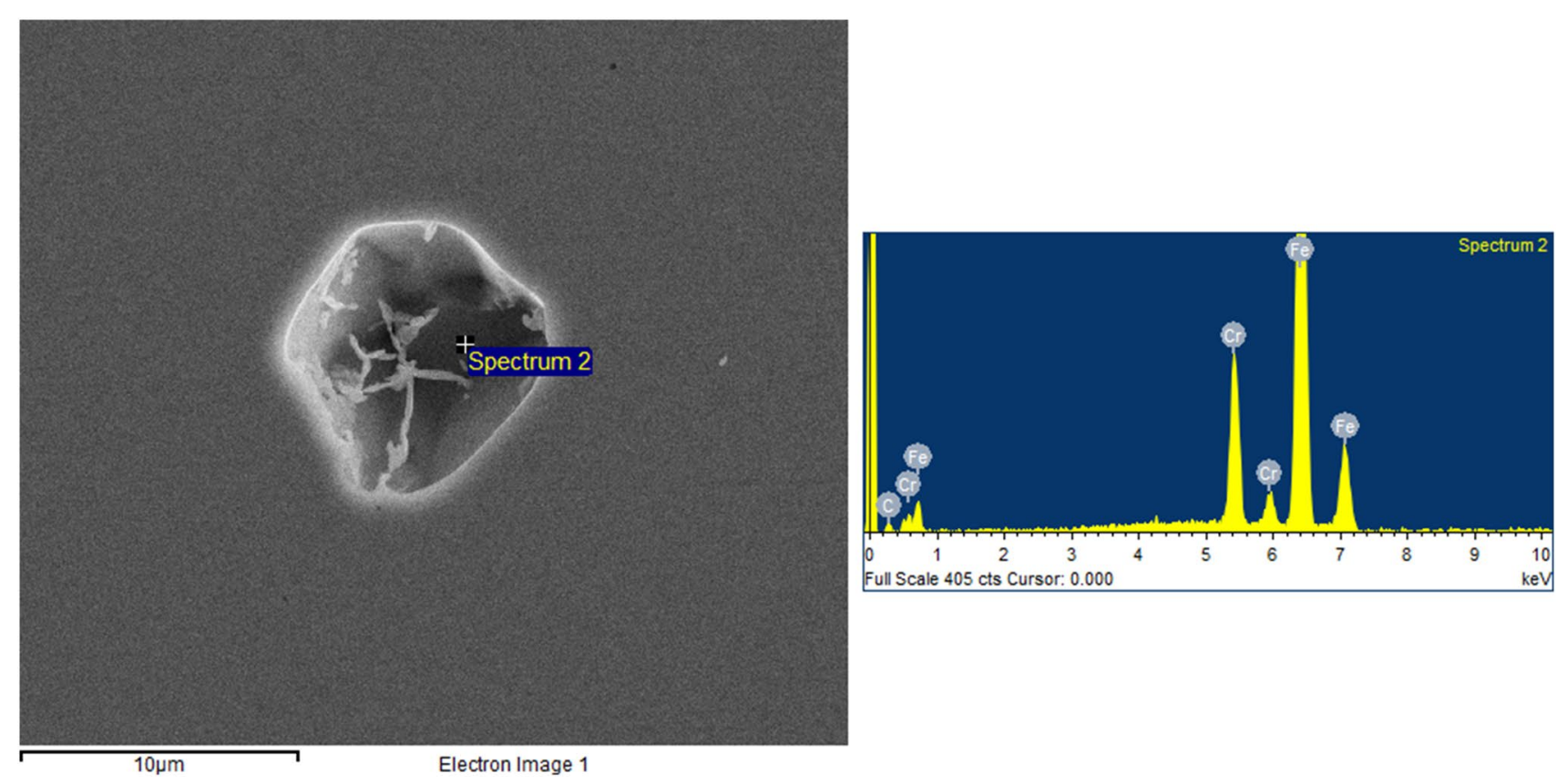

Fig. 10 SEM-EDS of unused chain 1.4742 (AISI F10) shows chromium in the microstructure
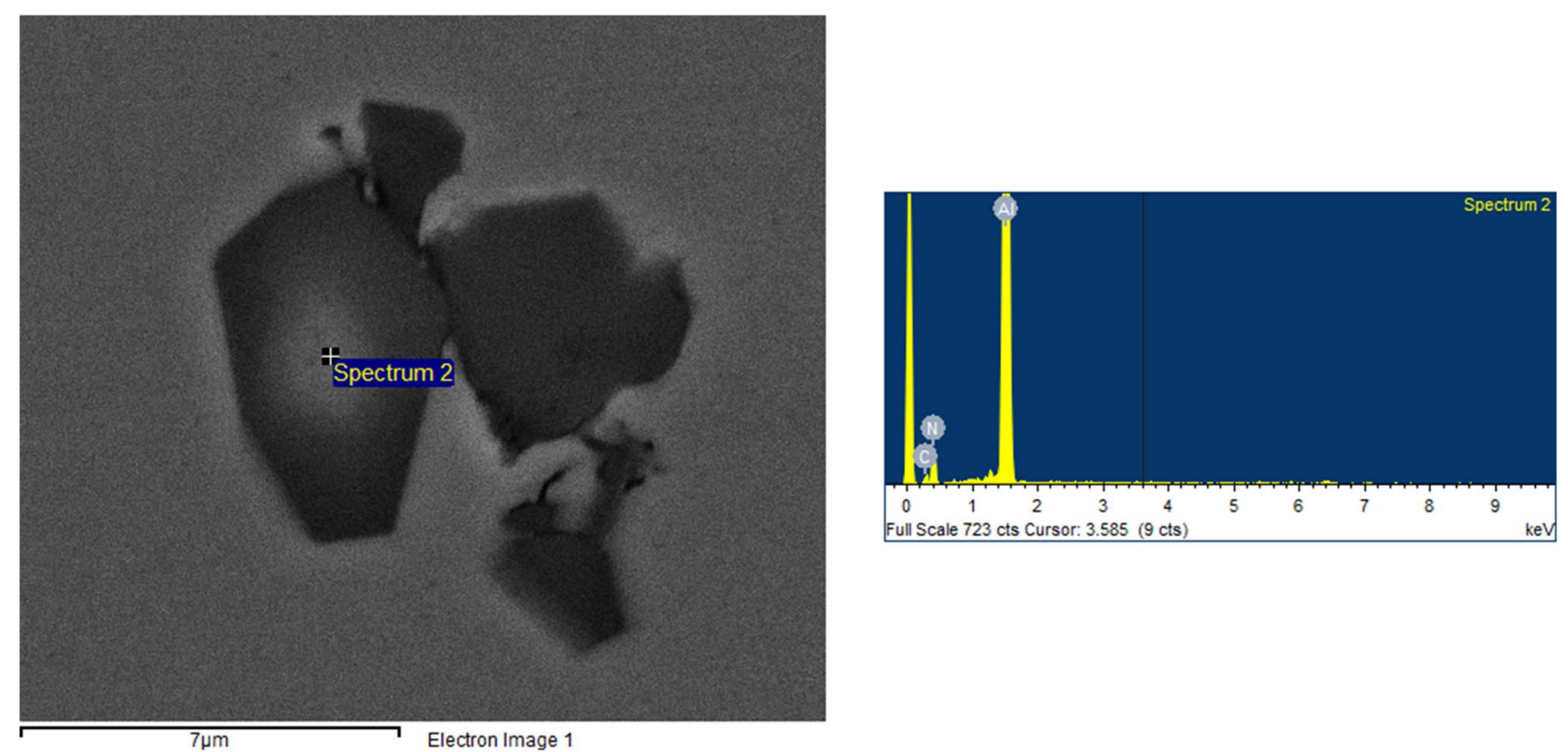

Fig. 11 SEM-EDS of unused chain 1.4742 (AISI F10) shows AIN in the microstructure

change in original diameter equal to $1 \mathrm{~mm}$ which resulted from creep behavior as less alloying elements exist in this steel grade (see Table 1). Creep will not be detailed in this work as it focuses mainly on elemental segregation; however, more details about creep can be found in Zauter et al. [10].
Table 3 shows the change in ring dimensions after 180 days of continuous working inside Kufa rotary cement kiln. Top rings have been recorded the maximum reduction in thickness; it also showed a significant deformation (oval shape) especially in the first rows (sample 11 and sample 13) as shown in Fig. 8 and Table 3. The oval shape of the top rings can be attributed to the uniform continuous 


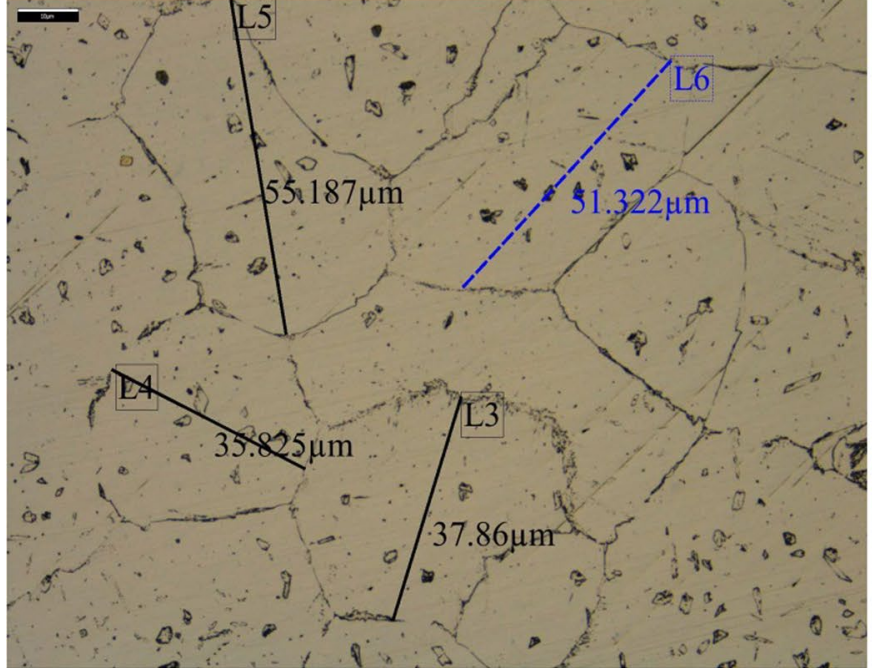

a



b

Fig. 12 Images of 30 days used chain DIN 1.4742 (AISI F10) first row, (a) optical microscopy, average grain size is $45 \mu \mathrm{m}$, and the dark second phase is chromium segregation. (b) SEM segregation of $\mathrm{Cr}$ at ferrite grain boundaries

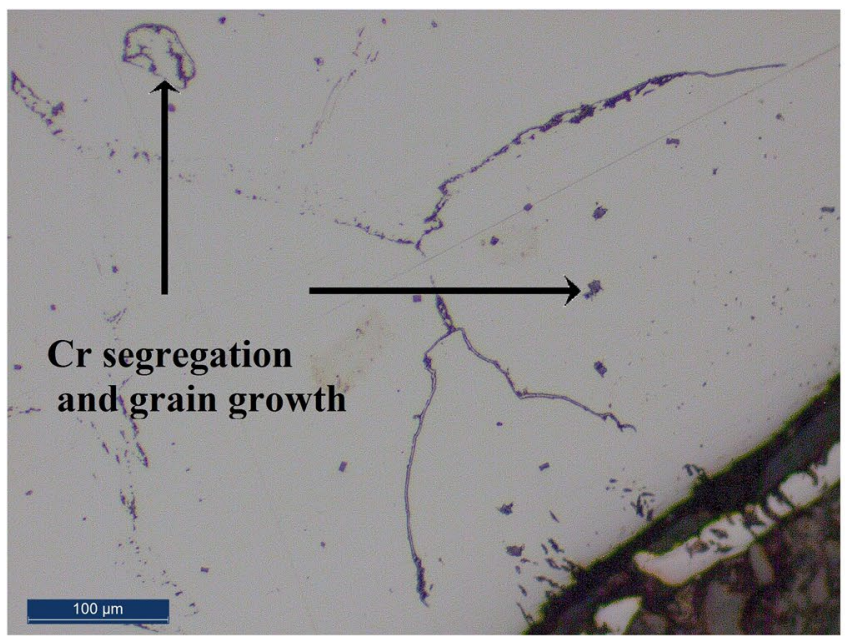

a

Fig. 13 Optical images of 180 days used chain DIN 1.4742 (AISI F10) first row, (a) chain edge, (b) chain middle, both images show grain growth and segregation of $\mathrm{Cr}$ within ferrite grain and also at

reduction in thickness and also to the creep behavior under the effect of loading and heating. Creep behavior needs more investigation, and the current study concentrates on the $\mathrm{Cr}$ segregation as a main cause of chains failure. The reduction in chains thickness as shown in Table 3 was independent on the rings distance from fire which can be attributed to the long continuous working. Example of that is samples 13 and 17 which showed higher reduction

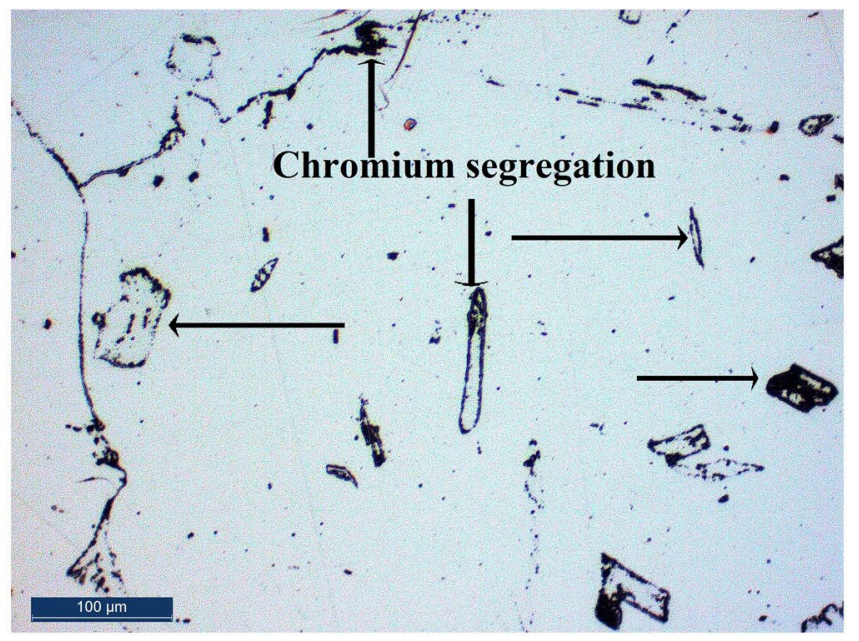

b

ferrite grains boundaries, average grain size is $550 \mu \mathrm{m}$. The dark second phase is chromium segregation

in thickness compared to samples 11 and 19 , despite the fact that the distance from fire was longer in the case of samples 13 and 17. This also can be noticed in sample 21 which showed the same reduction in thickness of sample 11 despite the high difference of the distance from fire. 


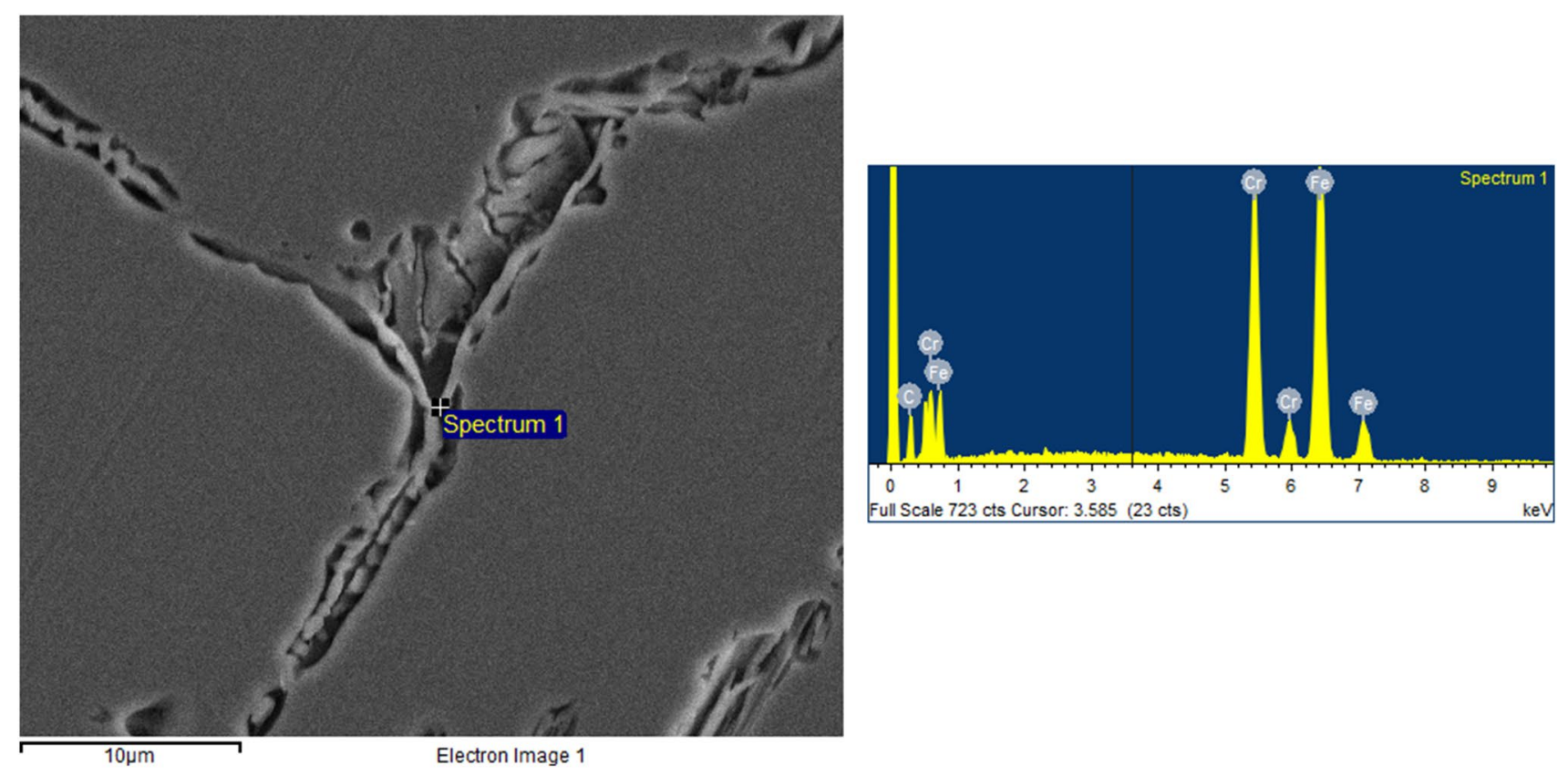

Fig. 14 SEM-EDS analysis shows Cr-C segregation at ferrite grain boundaries, used chain DIN 1.4742 (AISI F10) first row for 180 days



Fig. 15 SEM-EDS analysis shows Cr segregation around AIN, used chain DIN 1.4742 (AISI F10) first row for 180 days

\section{Microstructure and Hardness Examination of Unused and Used Chains of 1.4742 Steel Grade}

The microstructure of the unused 1.4742 steel grade as shown in Fig. 9 includes fine grains of ferrite with average grains size of $10 \mu \mathrm{m}$. The alloying elements under concern including $\mathrm{Cr}$ and $\mathrm{Al}$ are shown in the SEM-EDS in Figs. 10 and 11, respectively. Aluminum was found in a form of AIN which can control the ferrite grain size and thus increases the microstructure hardness [11]. Figure 12a and b shows the optical and SEM images of the chain microstructure after 30 days of continuous work inside the cement kiln. The microstructure has shown a grain growth with average grain size of $45 \mu \mathrm{m}$; this grain growth represents 4 times of 

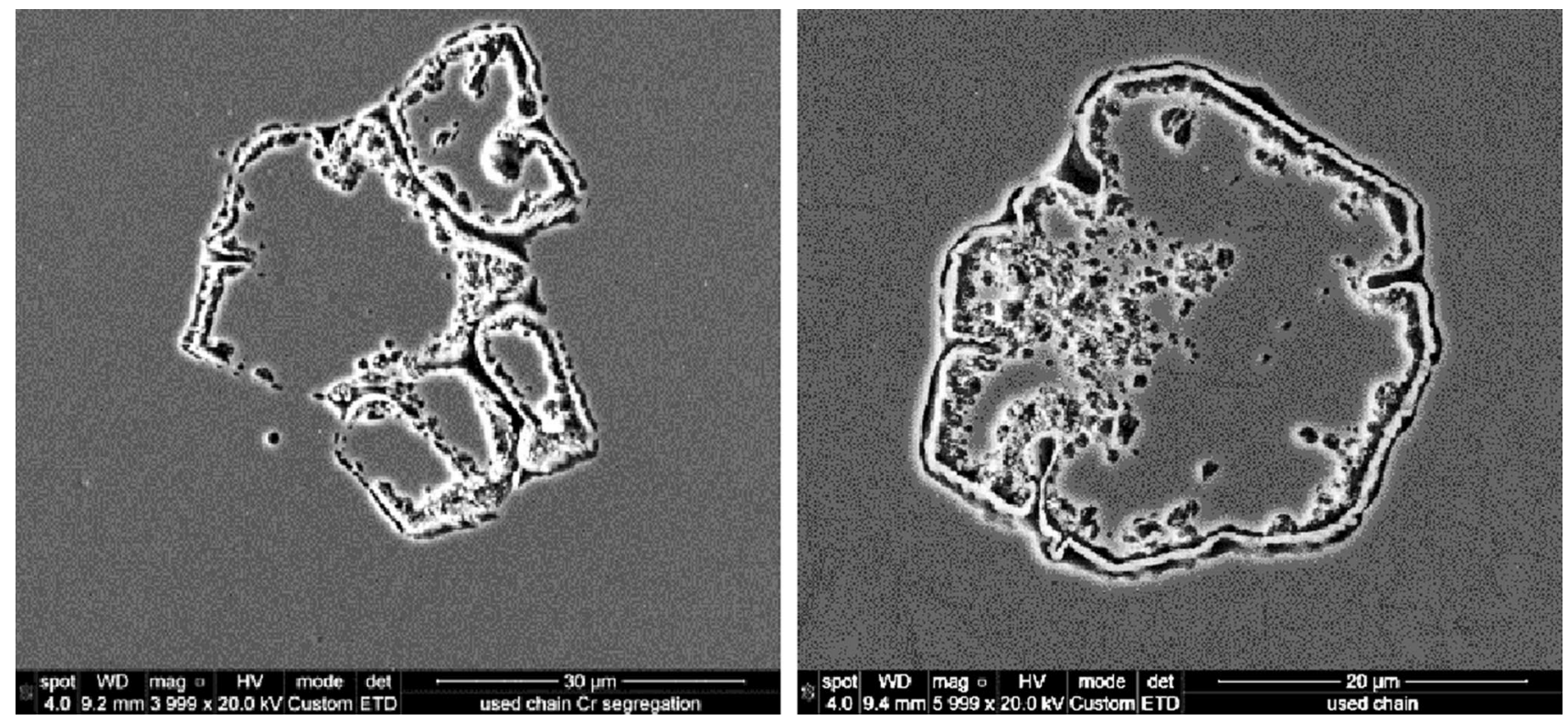

Fig. 16 SEM images show Cr segregation within ferrite grains, used chain DIN 1.4742 (AISI F10) first row for 180 days

Fig. $17 \mathrm{Cr}$ and $\mathrm{C}$ segregation within ferrite grains, SEM-EDS mapping technique, used DIN 1.4742 (AISI F10) first row for 180 days
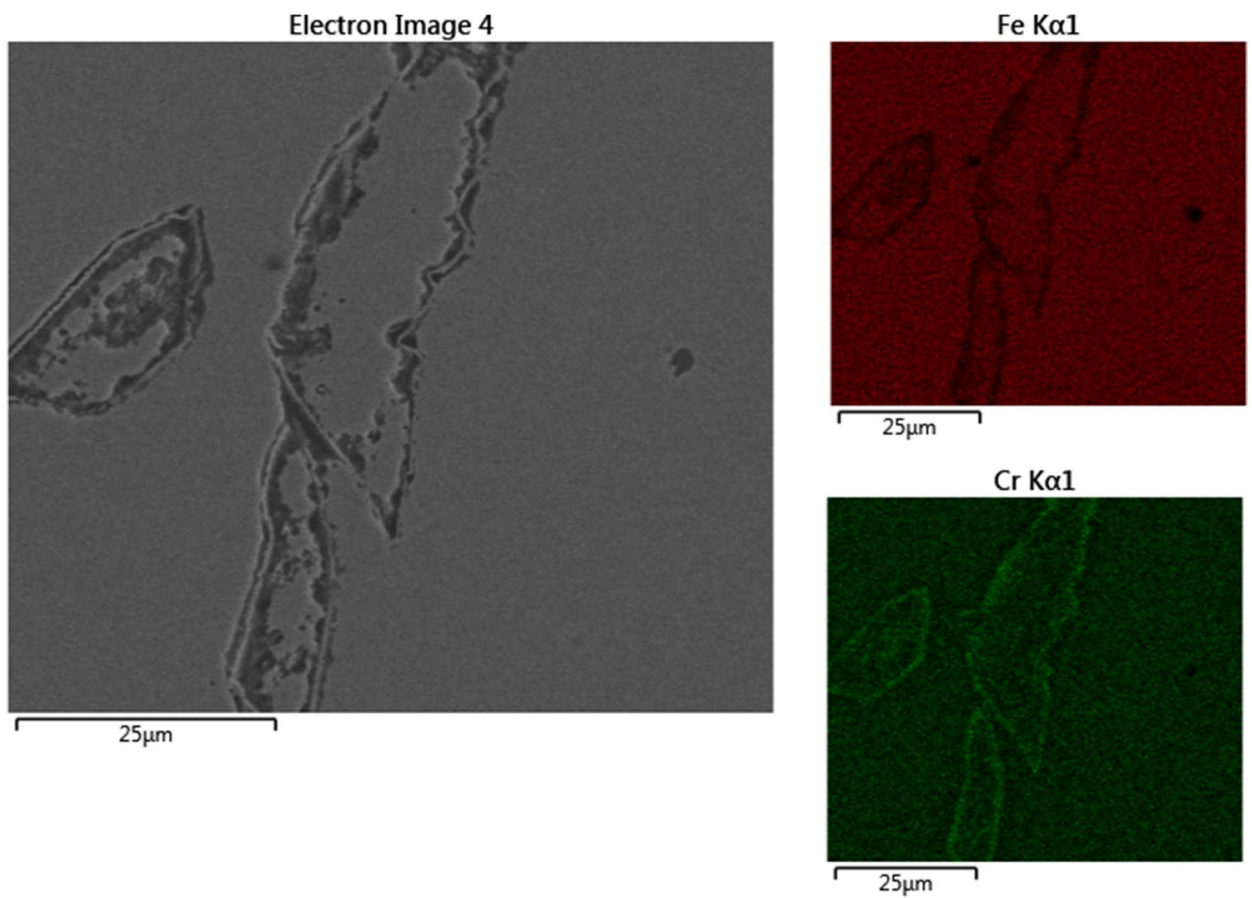

C K $\alpha 12$




Table 4 Chemical analysis (wt.\%) for samples 1-21

\begin{tabular}{|c|c|c|c|c|c|c|c|c|c|c|c|}
\hline & $\mathrm{C} \%$ & $\mathrm{Si} \%$ & $\mathrm{Mn} \%$ & $\mathrm{P} \%$ & $\mathrm{~S} \%$ & $\mathrm{Cr} \%$ & $\mathrm{Ni} \%$ & Мо $\%$ & $\mathrm{~A} 1 \%$ & $\mathrm{Cu} \%$ & $\mathrm{Co} \%$ \\
\hline Sample 1 & 0.083 & 0.879 & 0.432 & 0.014 & 0.0036 & 17.30 & 0.498 & 0.156 & 1.03 & 0.093 & 0.022 \\
\hline Sample 2 & 0.075 & 0.840 & 0.399 & 0.017 & 0.0040 & 17.22 & 0.156 & 0.076 & 1.10 & 0.079 & 0.019 \\
\hline Sample 3 & 0.075 & 0.888 & 0.399 & 0.015 & 0.0040 & 17.28 & 0.156 & 0.085 & 1.10 & 0.078 & 0.019 \\
\hline Sample 4 & 0.092 & 0.870 & 0.448 & 0.015 & 0.0047 & 17.37 & 0.225 & 0.079 & 0.849 & 0.098 & 0.020 \\
\hline Sample 5 & 0.150 & 0.223 & 0.477 & 0.014 & 0.024 & 0.0062 & 0.0074 & 0.0039 & 0.001 & 0.0098 & 0.0045 \\
\hline Sample 6 & 0.169 & 0.215 & 0.579 & 0.019 & 0.027 & 0.020 & 0.0069 & 0.0074 & 0.001 & 0.04 & 0.0059 \\
\hline Sample 7 & 0.162 & 0.161 & 0.517 & 0.023 & 0.022 & 0.028 & 0.0095 & 0.0061 & 0.001 & 0.03 & 0.0061 \\
\hline Sample 8 & 0.168 & 0.186 & 0.502 & 0.0096 & 0.019 & 0.018 & 0.0080 & 0.0063 & 0.001 & 0.027 & 0.0048 \\
\hline Sample 9 & 0.146 & 0.075 & 0.380 & 0.021 & 0.019 & 0.016 & 0.008 & 0.0037 & 0.001 & 0.010 & 0.0039 \\
\hline Sample 10 & 0.141 & 0.144 & 0.481 & 0.019 & 0.018 & 0.015 & 0.0082 & 0.0057 & 0.001 & 0.052 & 0.0066 \\
\hline Sample 11 & 0.139 & 0.779 & 0.405 & 0.001 & 0.0021 & 16.47 & 0.038 & 0.025 & 2.52 & 0.047 & 0.0020 \\
\hline Sample 12 & 0.078 & 0.861 & 0.416 & 0.014 & 0.0035 & 17.43 & 0.160 & 0.085 & 0.883 & 0.055 & 0.0180 \\
\hline Sample 13 & 0.082 & 0.796 & 0.340 & 0.0016 & 0.0070 & 16.93 & 0.155 & 0.071 & 0.827 & 0.105 & 0.0180 \\
\hline Sample 14 & 0.080 & 0.863 & 0.407 & 0.013 & 0.0039 & 17.39 & 0.139 & 0.089 & 0.929 & 0.048 & 0.0190 \\
\hline Sample 15 & 0.160 & 0.159 & 0.490 & 0.018 & 0.024 & 0.033 & 0.022 & 0.0063 & 0.0032 & 0.040 & 0.0053 \\
\hline Sample 16 & 0.149 & 0.158 & 0.500 & 0.017 & 0.022 & 0.027 & 0.026 & 0.0060 & 0.0010 & 0.039 & 0.0072 \\
\hline Sample 17 & 0.180 & 0.176 & 0.499 & 0.0074 & 0.018 & 0.023 & 0.010 & 0.0057 & 0.0010 & 0.032 & 0.0050 \\
\hline Sample 18 & 0.146 & 0.195 & 0.557 & 0.012 & 0.027 & 0.018 & 0.0092 & 0.0061 & 0.0010 & 0.037 & 0.0062 \\
\hline Sample 19 & 0.17 & 0.181 & 0.518 & 0.012 & 0.019 & 0.030 & 0.021 & 0.0077 & 0.0011 & 0.043 & 0.0067 \\
\hline Sample 20 & 0.145 & 0.199 & 0.531 & 0.0069 & 0.013 & 0.0089 & 0.0088 & 0.0046 & 0.0015 & 0.012 & 0.0074 \\
\hline \multirow[t]{2}{*}{ Sample 21} & 0.09 & 0.825 & 0.696 & 0.017 & 0.0047 & 18.30 & 0.532 & 0.117 & 0.908 & 0.109 & 0.018 \\
\hline & Ti\% & $\mathrm{Nb} \%$ & $\mathrm{~V} \%$ & $\mathrm{~W} \%$ & $\mathrm{~Pb} \%$ & $\mathrm{~B} \%$ & $\mathrm{Sn} \%$ & As $\%$ & $\mathrm{Bi} \%$ & $\mathrm{Ca} \%$ & $\mathrm{Fe} \%$ \\
\hline Sample 1 & 0.0074 & 0.004 & 0.084 & 0.010 & 0.0030 & 0.0007 & 0.0088 & 0.0019 & 0.0015 & 0.0004 & 79.38 \\
\hline Sample 2 & 0.0094 & 0.004 & 0.103 & 0.010 & 0.0030 & 0.0007 & 0.0077 & 0.0015 & 0.0015 & 0.0001 & 79.88 \\
\hline Sample 3 & 0.0094 & 0.004 & 0.105 & 0.010 & 0.0030 & 0.0008 & 0.010 & 0.0015 & 0.0015 & 0.0003 & 79.77 \\
\hline Sample 4 & 0.0054 & 0.004 & 0.103 & 0.010 & 0.0030 & 0.0009 & 0.0099 & 0.0019 & 0.0015 & 0.0010 & 79.81 \\
\hline Sample 5 & 0.0010 & 0.003 & 0.001 & 0.010 & 0.0030 & 0.0005 & 0.0010 & 0.0018 & 0.0020 & 0.0003 & 99.07 \\
\hline Sample 6 & 0.0010 & 0.003 & 0.0038 & 0.010 & 0.0030 & 0.0005 & 0.018 & 0.0016 & 0.0020 & 0.0006 & 98.86 \\
\hline Sample 7 & 0.0010 & 0.003 & 0.0033 & 0.010 & 0.0030 & 0.0005 & 0.014 & 0.0098 & 0.0020 & 0.0003 & 99.01 \\
\hline Sample 8 & 0.0010 & 0.003 & 0.0013 & 0.010 & 0.0030 & 0.0005 & 0.012 & 0.0082 & 0.0020 & 0.0039 & 99.03 \\
\hline Sample 9 & 0.0010 & 0.003 & 0.0010 & 0.010 & 0.0030 & 0.0005 & 0.016 & 0.0083 & 0.0020 & 0.0010 & 99.28 \\
\hline Sample 10 & 0.0010 & 0.003 & 0.0065 & 0.010 & 0.0030 & 0.0005 & 0.024 & 0.0140 & 0.0020 & 0.0003 & 99.01 \\
\hline Sample 11 & 0.0070 & 0.009 & 0.073 & 0.010 & 0.0030 & 0.0005 & 0.0040 & 0.0015 & 0.0015 & 0.0076 & 78.62 \\
\hline Sample 12 & 0.0057 & 0.004 & 0.089 & 0.010 & 0.0030 & 0.0006 & 0.0085 & 0.0015 & 0.0015 & 0.0005 & 79.88 \\
\hline Sample 13 & 0.0083 & 0.004 & 0.089 & 0.010 & 0.0030 & 0.0006 & 0.0063 & 0.0015 & 0.0015 & 0.0034 & 80.56 \\
\hline Sample 14 & 0.0095 & 0.004 & 0.104 & 0.010 & 0.0030 & 0.0007 & 0.0097 & 0.0020 & 0.0015 & 0.0006 & 79.89 \\
\hline Sample 15 & 0.0010 & 0.003 & 0.0015 & 0.010 & 0.0030 & 0.0005 & 0.018 & 0.018 & 0.0020 & 0.0014 & 99.00 \\
\hline Sample 16 & 0.0010 & 0.003 & 0.0016 & 0.010 & 0.0030 & 0.0005 & 0.019 & 0.016 & 0.0020 & 0.0005 & 99.01 \\
\hline Sample 17 & 0.0010 & 0.003 & 0.0021 & 0.010 & 0.0030 & 0.0005 & 0.016 & 0.0079 & 0.0020 & 0.0004 & 99.02 \\
\hline Sample 18 & 0.0010 & 0.003 & 0.0021 & 0.010 & 0.0030 & 0.0005 & 0.018 & 0.014 & 0.0020 & 0.0004 & 98.95 \\
\hline Sample 19 & 0.0010 & 0.003 & 0.0015 & 0.010 & 0.0030 & 0.0005 & 0.013 & 0.012 & 0.0020 & 0.0009 & 98.96 \\
\hline Sample 20 & 0.0010 & 0.003 & 0.0010 & 0.010 & 0.0030 & 0.0005 & 0.017 & 0.0019 & 0.0020 & 0.0004 & 99.05 \\
\hline Sample 21 & 0.0091 & 0.0044 & 0.047 & 0.010 & 0.003 & 0.001 & 0.011 & 0.0057 & 0.0015 & 0.0004 & 78.30 \\
\hline
\end{tabular}

the grain sizes of the unused chain. It is also shown that a segregation of chromium within the ferrite grains but more at the ferrite grain boundaries as shown in Fig. 12b has occurred. Figure 13 shows the higher grain growth of 1.4742 grade microstructure after 180 days of continuous work. The average grain size has reached $550 \mu \mathrm{m}$ due to grains coalescence, whereas chromium segregation (the second phase with dark color) is clear within the ferrite grains and also at 
Table 5 The difference in chemical composition ( $\mathrm{Cr}$ and C) of DIN 1.4742 (AISI F10) and St37 steel grades (wt.\%) after 180 days of continuous work

\begin{tabular}{llllll}
\hline & Steel grade & Top/bottom & $\begin{array}{l}\text { Working } \\
\text { period, days }\end{array}$ & The loss in C\% & The loss in Cr\% \\
\hline Sample 1 & 1.4742 & Top & 30 & -0.037 & -1.7 \\
Sample 2 & 1.4742 & Bottom & 30 & -0.045 & -1.78 \\
Sample 3 & 1.4742 & Top & 30 & -0.055 & -1.72 \\
Sample 4 & 1.4742 & Bottom & 30 & -0.028 & -1.63 \\
Sample 5 & St37 & Top & 30 & -0.02 & -0.2938 \\
Sample 6 & St37 & Bottom & 30 & -0.01 & -0.28 \\
Sample 7 & St37 & Top & 30 & -0.08 & -0.272 \\
Sample 8 & St37 & Bottom & 30 & -0.02 & -0.282 \\
Sample 9 & St37 & Top & 30 & -0.024 & -0.284 \\
Sample 10 & St37 & Bottom & 30 & -0.029 & -0.285 \\
Sample 11 & 1.4742 & Top & 180 & +0.019 & -2.53 \\
Sample 12 & 1.4742 & Bottom & 180 & -0.042 & -1.57 \\
Sample 13 & 1.4742 & Top & 180 & -0.038 & -2.07 \\
Sample 14 & 1.4742 & Bottom & 180 & -0.04 & -1.61 \\
Sample 15 & St37 & Top & 180 & -0.01 & -0.267 \\
Sample 16 & St37 & Bottom & 180 & -0.021 & -0.273 \\
Sample 17 & St37 & Top & 180 & +0.02 & -0.277 \\
Sample 18 & St37 & Bottom & 180 & -0.024 & -0.282 \\
Sample 19 & St37 & Top & 180 & +0.03 & -0.279 \\
Sample 20 & St37 & Bottom & 180 & -0.025 & -0.2911 \\
Sample 21 & 1.4742 & Top & 180 & -0.03 & -0.5 \\
\hline
\end{tabular}

Table 6 Proposal of steel grades according to the distance from the kiln flame

\begin{tabular}{|c|c|c|c|}
\hline $\begin{array}{l}\text { Distance } \\
\text { from the } \\
\text { fire }\end{array}$ & $\begin{array}{l}\text { Actual } \\
\text { material in } \\
\text { use }\end{array}$ & Our proposal & Reason \\
\hline 1st raw & 14.742 & 1.4892-115 MA & $\begin{array}{l}\text { Austenitic manganese steel grade that can hold up to } 1200^{\circ} \mathrm{C} \text {, the high amount of } \mathrm{Mn} \text { increases } \\
\text { protection of Ni and reduces } \mathrm{Cr} \text { segregation }[1,2]\end{array}$ \\
\hline $3.6 \mathrm{~m}$ & 14.742 & 1.4892-105 MA & $\begin{array}{l}\text { Austenitic manganese steel grade that can hold up to } 1000^{\circ} \mathrm{C} \text {, the high amount of } \mathrm{Mn} \text { increases } \\
\text { protection of } \mathrm{Ni} \text { and reduces } \mathrm{Cr} \text { segregation }[1,2]\end{array}$ \\
\hline $6.6 \mathrm{~m}$ & St 37 & 1.4724 (AISI 9F) & $\begin{array}{l}\text { A ferritic steel grade that can hold up to } 750^{\circ} \mathrm{C} \text {, the steel grade includes high amount of } \mathrm{Cr} \text {, i.e., } \\
13 \% \text {, which can increase the resistance toward corrosion }[1,2]\end{array}$ \\
\hline $10.8 \mathrm{~m}$ & St 37 & 1.4724 (AISI 9F) & $\begin{array}{l}\text { A ferritic steel grade that can hold up to } 750{ }^{\circ} \mathrm{C} \text {, the steel grade includes high amount of } \mathrm{Cr} \text {, i.e., } \\
13 \% \text { which can increase the resistance toward corrosion }[1,2]\end{array}$ \\
\hline $19.8 \mathrm{~m}$ & St 37 & $\begin{array}{l}\text { C35 (AISI } \\
\text { C1035) not } \\
\text { hardened }\end{array}$ & $\begin{array}{l}\text { Cheap ferrite/pearlite steel grade that can hold up to } 500^{\circ} \mathrm{C} \text {, as the temperature at this location is } \\
\text { no exceeding } 400{ }^{\circ} \mathrm{C}\end{array}$ \\
\hline $28.2 \mathrm{~m}$ & St 37 & C35 not hardened & $\begin{array}{l}\text { Cheap ferrite/pearlite steel grade that can hold up to } 500^{\circ} \mathrm{C} \text { as the temperature at this location is no } \\
\text { exceeding } 350{ }^{\circ} \mathrm{C}\end{array}$ \\
\hline
\end{tabular}

ferrite grain boundaries. Chromium segregation as revealed by SEM-EDS shown in Fig. 14 has taken a band-like shape. It also segregated around the AlN precipitates as shown in Fig. 15. Within the ferrite grains, chromium segregated in closed rings as shown in Fig. 16a and b. The band-like pattern segregation of $\mathrm{Cr}$ has reported previously in 434 stainless steel as a result of experiencing hot rolling [7]. The $\mathrm{Cr}$ segregation has been mentioned in the literature review and interpreted as micro-galvanic corrosion that cause a $\mathrm{Cr}$ segregation, the steel grain act as anode whereas the grain boundary act as cathode [4].

The microhardness test of the unused chain has shown an average value of $180 \mathrm{HV} \mathrm{Kgf} / \mathrm{mm}^{2}$, whereas the used chain (180 days of continuous working) has shown localized microhardness. An average value of $166 \mathrm{HV} \mathrm{Kgf} / \mathrm{mm}^{2}$ in the microstructure away from the chromium segregation regions 
has been measured. The decrease in the microhardness of the used chain can be attributed to the grain growth which in turn has reduced the grain boundaries density, and thus, wear resistance is expected to decrease. The regions which showed $\mathrm{Cr}$ segregation have shown higher microhardness value of $200 \mathrm{HV} \mathrm{Kgf} / \mathrm{mm}^{2}$ as a result of forming mainly chromium carbides as revealed by SEM-EDS mapping in Fig. 17.

\section{Chemical Analysis}

Although the chemical analysis has been carried out for many alloying elements, the focus will be on the chromium and carbon as these elements showed a significant segregation in the used chain microstructure as discussed in the previous section. Generally speaking, most of the alloying elements have shown a decrease in the chemical percentage (wt.\%) as a result of segregation. The decrease in wt.\% of chromium due to segregation in 1.4742 grade has ranged from 2.5 at the top chain to 1.5 at bottom chain in the first row as reported in Table 5 samples 11 and 12, respectively. The average loss of carbon alloying element in 1.4742 steel grade after 180 days of continuous work was about $0.04 \%$ as shown in Table 5. St37 steel grade showed a significant loss of $\mathrm{Cr}$ in the microstructure reached to $0.28 \%$ compare to $0.3 \%$ the total percentage exist in the microstructure. The average loss of carbon after 180 days of continuous work was about 0.025 . Table 6 suggests a new steel grades to be used in Kufa rotary cement kilns according to the result of this study and depending on the location from the fire. Austenitic manganese steel grades were suggested at the first row until $5 \mathrm{~m}$ from the fire as these grades can hold at very high temperatures. The higher percentage of Mn that exists in this new steel grade can increase the protection of $\mathrm{Ni}$ and is expected to reduce $\mathrm{Cr}$ segregation [1,2].

\section{Conclusion}

In conclusion, the kiln chain failure has been investigated by carrying out many experiments including chemical analysis, optical images, SEM-EDS, and microhardness. The loss of alloying elements especially chromium due to the segregation has been detected as the main reason for the kiln chain failure. Chromium losing from the chains microstructure has reduced the corrosion resistance. The grains growth during service period has also increased the possibility of peeling the material away from the chain surface which in turn caused in reduction of thickness and also chains deformation. Using higher steel grades in the first row until 4-5 m from the cement kiln fire can increase chains longevity and reduce the chains failure. Such steel grades which include higher amount of Mn are 1.4892-115 MA and 1.4892-105 MA.

\section{Future Work}

- To examine the duty of the suggested chains and to compare with the current chains.

- To carry out thermo-mechanical tests on the chains including creep and hot bending.

Acknowledgments The author would like to thank the Ministry of Higher Education/the Research and Development Department, Iraq, and Kufa cement plant for funding this pioneer research project. The authors also would like to thank Mr. Khudier Abbas for his help in collecting data and samples.

Open Access This article is distributed under the terms of the Creative Commons Attribution 4.0 International License (http://creativeco mmons.org/licenses/by/4.0/), which permits unrestricted use, distribution, and reproduction in any medium, provided you give appropriate credit to the original author(s) and the source, provide a link to the Creative Commons license, and indicate if changes were made.

\section{References}

1. Advanced Material Handling LTD., Kiln Chains and Accessories. http://www.advancedmaterial.ca/wp-content/uploads/2016/02/ kiln_chain_brochure.pdf. Accessed May 2017

2. Heko Ketten GmbH, Kiln Chains and Accessories for Wet and Long-Dry Rotary Kilns. http://www.heko.com/index.php?id=306. Accessed May 2017

3. D. Stavrev, Ts. Dikova, Corrosion of $\mathrm{Cr}-\mathrm{Mn}-\mathrm{Ni}$ heat-resistant steel under thermocyclic and mechanical impact in furnace media. Scientific Proceedings (VIII) International Congress "Machines, Technologies, Materials" (2011), pp. 5-8

4. S.A. Park, W.S. Ji, J.G. Kim, Effect of chromium on the corrosion behaviour of low-alloy steels containing copper in FGD environment. Int. J. Electrochem. Sci. 8, 7498-7509 (2013)

5. L.V. Saraf, A.S. Lea, C.M. Wang, A. Dohnalkova, B.W. Arey, Chromium segregation at the grain boundaries in $\mathrm{Ni}-\mathrm{Fe}-\mathrm{Cr}$ alloy. Microsc. Microanal. 16(2), 690-691 (2010)

6. M.S. Laws, P.J. Goodhew, Grain boundary structure and chromium segregation in a 316 stainless steel. Acta Metall. Mater. 39(7), 1525-1533 (1991)

7. J.D. Defilippi, H.-C. Chao, Effect of chromium and molybdenum segregation on the ridging behaviour of 434 stainless steel. Metallurgical Transactions 2, 3209 (1971)

8. E. Yoshihide, S. Noritaka, Influence of background on iron and steel analysis by inductively coupled plasma atomic emission spectrometry. Transactions ISIJ 23, 789-795 (1983)

9. P.J. Cunat, Alloying Elements in Stainless Steel and Other Chromium-Containing Alloys (2004). Published in cooperation with the International Chromium Development Association, The publication is available in print from ICDA, 45 Rue de Lisbonne, F-75008 Paris, () Euro Inox 2004. www.euroinox.org

10. R. Zauter, E. Petry, H.J. Christ, H. Mughrabi, High temperature creep behaviour and microstructure development of AISI 304L stainless steel. Mater. Sci. Eng., A 124, 125-132 (1990)

11. F.G. Wilson, T. Gladman, Aluminum nitride in steel. Int. Mater. Rev. 33(1), 221-286 (1988). http://www.tandfonline.com/doi/ abs/10.1179/imr.1988.33.1.221 